\title{
部分安定化ジルコニアの疲労特性に及ぼすアニールの影響
}

\author{
吉川 晃 ${ }^{* 1}$ ，池田 清彦*2，越智 秀*3，小堀 修身*1
}

\section{Effect of annealing on fatigue behavior of partially stabilized zirconia}

\author{
Akira YOSHIKAWA ${ }^{* 1}$, Kiyohiko IKEDA ${ }^{* 2}$, Hiizu OCHI ${ }^{* 3}$ and Osami KOBORI ${ }^{* 1}$ \\ ${ }^{* 1}$ Department of Mechanical Engineering, Osaka Sangyo University \\ 3-1-1 Nakagaito Daito-shi, Osaka 574-8530, Japan \\ ${ }^{* 2}$ Department of Mechanical Systems Engineering, University of Miyazaki \\ 1-1 Gakuen Kibanadai-nishi, Miyazaki-shi, Miyazaki 889-2192, Japan \\ ${ }^{* 3}$ Research Center, Osaka Institute of Technology \\ 5-16-1 Omiya Asahi-ku, Osaka-shi, Osaka 535-8585, Japan
}

Received: 7 September 2016; Revised: 5 December 2016; Accepted: 21 March 2017

\begin{abstract}
Interest in applications of stabilized zirconia (PSZ) as dental material has recently increased. In a corrosive environment such as a living body, PSZ is subjected to a cyclic load and needs higher fatigue strength. In our previous paper, appreciable degradation occurred in the fatigue lifetime of yttria-doped tetragonal zirconia polycrystals (TZP). In this study, PSZ specimens were annealed for $100 \mathrm{~h}$ at temperatures of 200,400 and $600^{\circ} \mathrm{C}$ in a low vacuum atmosphere to improve the fatigue resistance. Both static and cyclic fatigue tests were conducted on the annealed specimens under static four-point bending and under cyclic reversed plane bending, respectively. As a comparison, specimens without annealing were tested in the same way. The test results indicated that the lifetime appreciably increases in cycling fatigue under a low applied load in specimens annealed at the low temperatures of 200 and $400^{\circ} \mathrm{C}$ from that of specimens without annealing. It was supposed that the occurrence of fine microcracks accompanied by the phase transformation from tetragonal to monoclinic caused enlargement of the process zone in the wake field of a crack in cyclic loading and contributed to the increase of crack resistance.
\end{abstract}

Key words : Tetragonal zirconia polycrystals, Anneal, Fatigue, Slow crack growth, Process zone

\section{1. 緒言}

近年, 部分安定化ジルコニアは強勒性のみならず優れた生体親和性から医療用としての注目が高まってきてい る. そこでは，生体という腐食されやすい環境下で，常時繰返し負荷が加わることが考えられ，而疲労特性が要 求される，著者らは前報（吉川他，2014）において，本材料はセラミックスの中でも特に高強度，高勒性を有す るにも関わらず顕著な SCG（Slow Crack Growth）特性を有すると共に，応力繰返しによる疲労寿命の低下が大き いことを見出した．そのことから，低応力下で繰返し負荷が加わる場合の使用における注意を喚起すると共に， 繰返し負荷における疲労寿命低下抑制を考慮した材料の改善が必要であることを提言した。ここで用いた部分安 定化ジルコニアはイットリアを $3 \mathrm{~mol} \%$ 添加して特殊な熱処理を施すことにより, 高温安定相の正方晶になるよう に調整した正方晶ジルコニア多結晶体（TZP: Tetragonal Zirconia Polycrystals）と呼ばれるものである．したがって 低温では準安定相であり，低温でアニール（焼鈍）処理を施すと準安定相の正方晶から低温安定相の単斜晶への 相変態が起こり組織の安定化が期待される. 一方では, $200^{\circ} \mathrm{C}$ 付近の低温アニールでは著しく強度が劣化し，そ の強度劣化はアニール中に大気中に含まれる $\mathrm{H}_{2} \mathrm{O}$ 分子が相変態を著しく促進させることによって表面き裂が発 生することに起因することが言われている（佐藤, 島田, 1989)。そのような観点から, 本研究では繰返し疲労寿

No.16-00411 [DOI:10.1299/transjsme.16-00411], J-STAGE Advance Publication date: 10 April, 2017

${ }^{* 1}$ 正員, 大阪産業大学 工学部（广574-8530 大阪府大東市中垣内 3-1-1）

*2 正員, 宮崎大学 名誉教授（干889-2192 宮崎県宮崎市学園木花台西 1-1）

*3 大阪工業大学 (干535-8585 大阪府大阪市旭区大宮 5-16-1)

E-mail of corresponding author: yosikawa@mech.osaka-sandai.ac.jp 
命低下抑制対策の一つの試みとして，真空中でアニール処理を施し，負荷が加わる前に正方晶の一部を予め単斜 晶に相変態させ，負荷が作用した際に応力誘起変態によって形成されるプロセスゾーンの領域を拡大させること により，き裂進展抵抗を増大させることを考えた，具体的には，上記アニール処理試験片について静疲労及び繰 返し疲労試験を行い, 疲労特性に及ぼすアニールの影響について調べると共に, 繰返し疲労寿命低下抑制の立場 から最適なアニール条件を検討した。

\section{2. 実験方法}

\section{$2 \cdot 1$ 供試材および試験片}

供試材は $3 \mathrm{~mol} \%$ の $\mathrm{Y}_{2} \mathrm{O}_{3}$ を添加し $1500{ }^{\circ} \mathrm{C}, \quad 1$ 時間常圧焼結させた市販の部分安定化ジルコニア（株）エム ケーセラ製）であり，その大部分は結晶粒径 $0.3 \mu \mathrm{m} \sim 1 \mu \mathrm{m}$ の正方晶 $\mathrm{ZrO}_{2}$ 粒子から成る（吉川他，2014）。化学組 成及び機械的性質を表 1 及び表 2 に示寸. 供試材は図 1 のように $3 \times 4 \times 40 \mathrm{~mm}$ の矩形状の試験片をダイヤモンド砥 石で切断し, 側面には研磨加工を施した後, 面精度を出すためにラップ処理を行った. 研磨処理を施した試験片 は, 電気炉を用いて真空雾囲気中で熱処理を行った. 熱処理条件を $\mathrm{Y}_{2} \mathrm{O}_{3}-\mathrm{ZrO}_{2}$ 平衡状態図 (Claussen,1984） と共 に説明したものを図 2 に示寸. 本材料は 3mol\% のイットリアを添加することにより室温でも焼結時の結晶組織 である正方晶を維持するように調整したものである．したがって，アニール処理を施すことにより，単斜晶が析 出し始めることが考えられる. ここでは, 予め単斜晶を析出させることを目的として試験片を炉内で設定温度

$\left(200^{\circ} \mathrm{C}, 400^{\circ} \mathrm{C}, 600^{\circ} \mathrm{C}\right.$ の 3 段階) に昇温し，100h一定温度を保持した後，炉冷することによりアニール処理を 施した，その際，上記の低温でのアニールにおける強度劣化を避けるため，アニール中，ロータリーポンプを作 動し炉内が低真空状態を維持するようにした.

以上のようなアニール処理を施した曲げ試験片の引張応力側表面の中央にビッカース圧子を $98 \mathrm{~N}$ の荷重で $30 \mathrm{~s}$ 押し込み, 表面長さ $290 \mu \mathrm{m}$, 深さ $120 \mu \mathrm{m}$, アスペクト比約 0.83 の半楕円状予き裂を導入した.

Table 1 Chemical compositions of partially stabilized zirconia (mass \%).

\begin{tabular}{|c|c|c|c|c|c|}
\hline $\mathrm{Y}_{2} \mathrm{O}_{3}$ & $\mathrm{Al}_{2} \mathrm{O}_{3}$ & $\mathrm{SiO}_{2}$ & $\mathrm{Fe}_{2} \mathrm{O}_{3}$ & $\mathrm{Na}_{2} \mathrm{O}$ & Ig. loss \\
\hline 5.3 & 0.255 & 0.002 & 0.002 & 0.012 & 3.39 \\
\hline
\end{tabular}

Table 2 Mechanical properties of partially stabilized zirconia .

\begin{tabular}{|c|c|c|c|c|c|c|c|c|}
\hline $\begin{array}{l}\text { Density } \\
{\left[\mathrm{g} / \mathrm{cm}^{3}\right]}\end{array}$ & $\begin{array}{c}\text { Young`s } \\
\text { modulus } \\
\text { [GPa] }\end{array}$ & $\begin{array}{c}\text { Fracture } \\
\text { toughness } \\
{\left[\mathrm{MPa} \cdot \mathrm{m}^{1 / 2}\right]}\end{array}$ & $\begin{array}{c}\text { Hardness } \\
\text { [Hv] }\end{array}$ & $\begin{array}{l}\text { Fracture } \\
\text { strength } \\
\text { [MPa] }\end{array}$ & $\begin{array}{l}\text { Thermal } \\
\text { expansion } \\
\text { coefficient } \\
{\left[\times 10^{-6} /{ }^{\circ} \mathrm{C}\right]}\end{array}$ & $\begin{array}{c}\text { Thermal } \\
\text { conductivity } \\
{\left[\mathrm{cal} / \mathrm{cm} / \mathrm{s}^{\circ} \mathrm{C} \text { ] }\right.}\end{array}$ & $\begin{array}{c}\text { Thermal } \\
\text { shock } \\
\text { resistance } \\
{\left[{ }^{\circ} \mathrm{C}\right]}\end{array}$ & $\begin{array}{r}\text { Electrical } \\
\text { resistivity } \\
{[\Omega \cdot \mathrm{cm}]}\end{array}$ \\
\hline 6.05 & 200 & 4.72 & 1300 & 1200 & 9 & 0.007 & 330 & $10^{12}$ \\
\hline
\end{tabular}

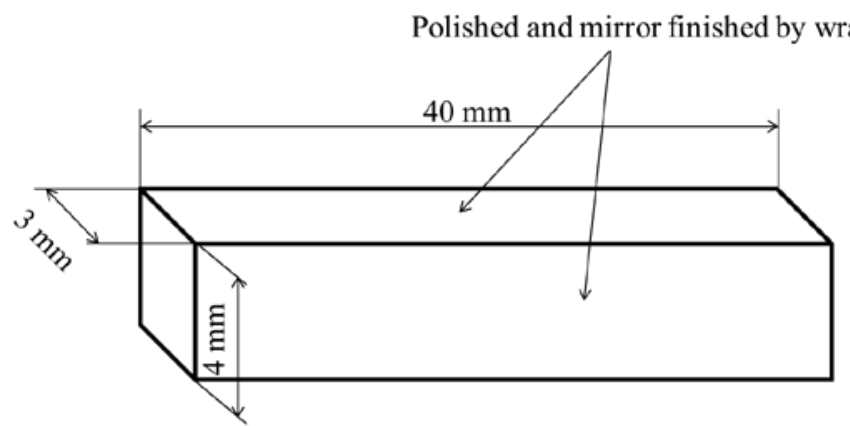

Fig. 1 Shape and dimensions of the specimen. The upper and lower surfaces ( $3 \mathrm{~mm} \times 40 \mathrm{~mm})$, and both side faces $(4 \mathrm{~mm} \times 40 \mathrm{~mm})$ of the specimen were polished and mirror finished by wrapping. The edges were planed off using a chamfering machine. 


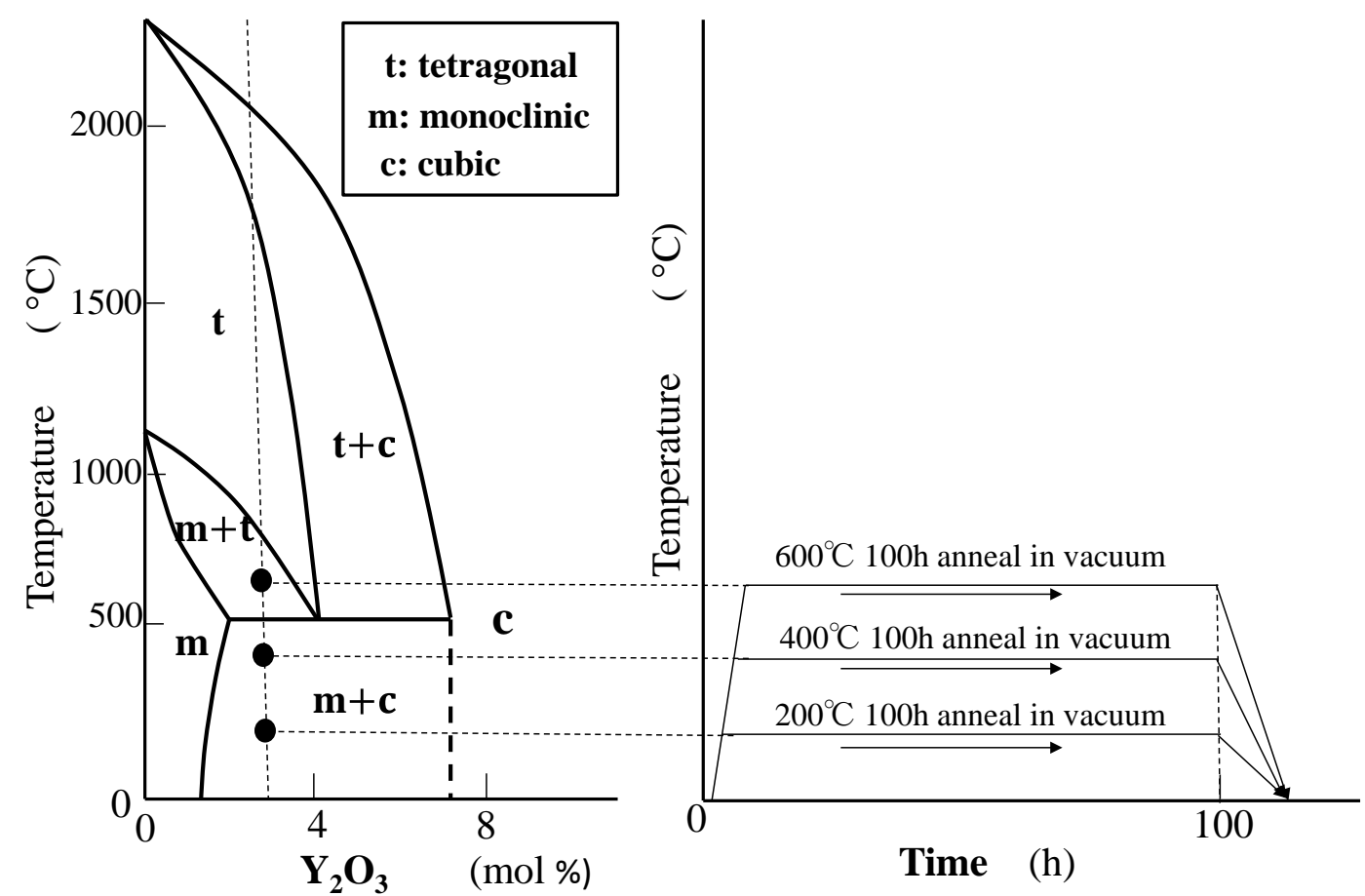

Fig. 2 Phase diagram of $\mathrm{ZrO}_{2}-\mathrm{Y}_{2} \mathrm{O}_{3}$ system and annealing condition. The materials were annealed for $100 \mathrm{~h}$ at the temperatures of 200,400 , and $600^{\circ} \mathrm{C}$ to improve the decreases in the fatigue resistance. These temperatures are lower than the temperature in which the monoclinic phase precipitates from the tetragonal phase.

\section{$2 \cdot 2$ 即時破壊強度試験}

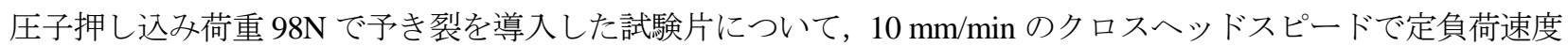
下で外部スパン $30 \mathrm{~mm}$, 内部スパン $10 \mathrm{~mm}$ の四点曲げ負荷を加え, 同一アニール温度について各 5 本の試験片を 破壊した.

\section{$2 \cdot 3$ 静疲労及び繰返し疲労試験}

静疲労試験においては外部スパン $26 \mathrm{~mm}$, 内部スパン $9 \mathrm{~mm}$ の四点曲げ負荷治具に圧子押し込み荷重 $98 \mathrm{~N} て ゙\}$ き裂を導入した試験片を取り付け，上部から重りを静かに載せて試験片に外力一定の死荷重を加え，破断までの

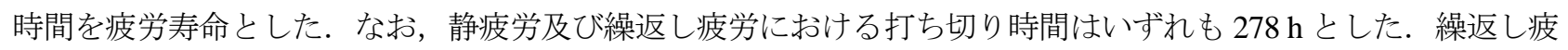
労試験においては東京衡機製作所製のシェンク式平面曲げ疲労試験機（PWOG-L 型）を用い，上記と同様な試験 片を片持ちばり曲げ負荷治具に取り付け，偏心円板とクランクにより，周波数 $10 \mathrm{~Hz}$ ，応力比 $\mathrm{R}=-1$ の正弦波形 による両振り繰返し負荷を加え，破断までの繰返し数を破断時間に換算したものを疲労寿命とした．いずれも室 温, 大気中, 相対湿度 60〜85\%の環境下で行った. なお, 予き裂はビッカース圧子によって導入したものであり, 試験片の厚さに比較してき裂深さが小さいので，試験片表面に生ずる最大応力を曲げ応力と定義した.

\section{2-4 XRD 回折及び超音波試験}

アニールによる相変態の程度を検証するために，XRD 回折と超音波試験を併用した．XRD 回折においては疲 労試験前及び疲労試験後の両方の引張側表面に X 線回折装置（RINT2200,Rigaku，Cu管球使用）によりX 線を入 射し，回折強度を測定した。なお，X線照射位置については試験片引張側表面を照射面にして同一熱処理及び同 一負荷処理のものを数本束にして両面テープで接着した後, 試験片長手方向より, 引張応力面ビッカース圧子導 入部をめがけて X 線を照射した，超音波試験は音弾性法(小堀, 岩清水, 1988), (岩清水, 2004) を用いた. 寸な わち, 図 3 に示すように超音波試験用に用意した幅 $20 \mathrm{~mm}$, 長さ $40 \mathrm{~mm}$, 厚さ $6 \mathrm{~mm}$ の矩形状の試験片の底面 $\left(\mathrm{X}_{2} \mathrm{X}_{3}\right.$ 
面）を支持台に接着し， $\mathrm{X}_{1}$ 方向に単軸圧縮応力を加えながら，上面（ $\mathrm{X}_{1} \mathrm{X}_{2}$ 面）中央部から厚さ方向（ $\mathrm{X}_{3}$ 方向） に超音波を入射し， $X_{3}$ 方向への波の伝ぱを測定する．このとき応力に垂直な方向（ $\mathrm{X}_{3}$ 軸）に伝ぱする縦波の音速 を $V_{\mathrm{L}}$ ，応力に平行な方向（ $\mathrm{X}_{1}$ 軸）及び垂直な方向（ $\mathrm{X}_{2}$ 軸）に振動しながら伝ぱする横波の音速を $V_{1}$ 及び $V_{2}$ とす る. 各方向の音速変化と単軸圧縮応力との間には近似的に線形関係があり, 次式が成り立つ.

$$
\begin{aligned}
& \frac{\Delta V_{i}}{V_{0}}=K_{i} \sigma_{a}(i=L, 1,2) \\
& K_{L}=\frac{\mu\left(\lambda+v_{1}+2 v_{2}\right)-\lambda\left(2 \lambda+5 \mu+2 v_{2}+4 v_{3}\right)}{2 \mu(\lambda+2 \mu)(3 \lambda+2 \mu)} \\
& K_{1}=\frac{\mu v_{2}+(\lambda+2 \mu)\left(\mu+v_{3}\right)}{2 \mu^{2}(3 \lambda+2 \mu)} \\
& K_{2}=\frac{\mu v_{2}+2 \lambda\left(\mu+v_{3}\right)}{2 \mu^{2}(3 \lambda+2 \mu)}
\end{aligned}
$$

ここで， $V_{0}$ は各波の初速，添字 $\mathrm{i}$ は縦波で $\mathrm{L} ，$ 横波で 1,2 を表し，比例定数 $K_{\mathrm{i}}(\mathrm{i}=\mathrm{L}, 1,2)$ は音弾性定数と呼ばれて いる. また, $\lambda$ と $\mu$ はラーメの定数 (二次の弾性定数) $, v_{1}, v_{2}, v_{3}$ は三次の弾性定数と呼ばれているものである. したがって，音弾性測定によって得られた音弾性定数 $K_{\mathrm{L}}, K_{1}$ 及び $K_{2}$ とラーメの定数 $\lambda$ と $\mu$ を式(2) (4)に代入す ることによって三次の弹性定数 $v_{1}, v_{2}, v_{3}$ を算出することができる.

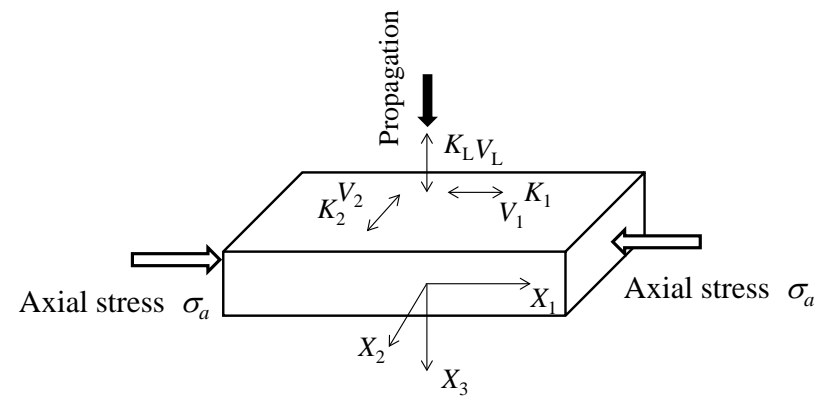

(a)

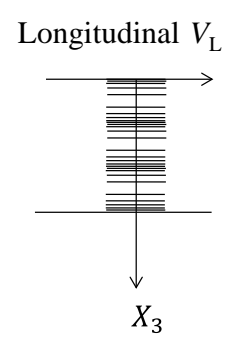

$X_{3}$

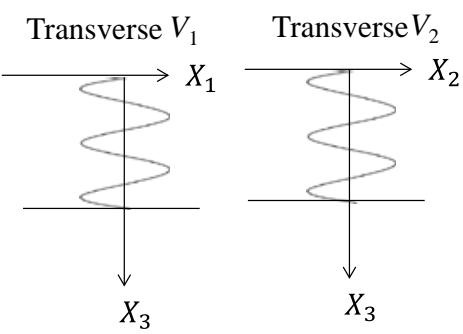

(b)

Fig.3 Measurements of third-order elastic constants. The elastic constants were determined by measuring their ultrasonic velocities under uniaxial compressive stress. The longitudinal and transverse waves polarized parallel or perpendicular to the uniaxial stress axis propagating to the $\mathrm{X}_{3}$ direction. (a) Axial stress and wave propagation. (b) Longitudinal velocity $V_{\mathrm{L}}$, and transverse velocities $V_{1}$ and $V_{2}$.

なお，音速の測定には図 4 に示寸ようなシングアラウンド測定（福岡，1994）を採用した．すなわち試験片を 台座に固定して表面から超音波を入射させる．超音波の送受信用には圧電セラミックを用いた．パルス発生器で 電圧パルスを発生し，試験片中へ立ち上がりの鋭い波数の少ないパルス波を試験片上面に取り付けた探触子から 送信する，送信パルスは試験片内厚さ方向を伝ぱして試験片底面で反射し，反射波が同じ探触子に受信される. 反射波は受信アンプで一定の振幅に増幅し, 試験片内の超音波の残響が消滅するまで一定の遅延時間 $T_{\mathrm{e}}$ 待った後, 再び送信パルスを出す．この操作を繰返してシングアラウンドさせ，この周期をカウンターで読む. 繰返しの周 期は試験片の伝ぱ時間 $T_{\mathrm{a}}$ と遅延時間 $T_{\mathrm{e}}$ との和になっているので, 任意の二つの反射波に対する周期 $T_{\mathrm{e} 1}\left(=T_{\mathrm{a} 1}+T_{\mathrm{e}}\right)$ と $T_{\mathrm{e} 2}\left(=T_{\mathrm{a} 2}+T_{\mathrm{e} 1}\right)$ を測定すれば，試験片上面，下面間の往復距離 $2 t （ t$ ：試験片の厚さ）をそれらの周期の差 $\left(T_{\mathrm{e} 2}-\right.$ $\left.T_{\mathrm{e} 1}\right)$ で除すことにより次式のように求めることができる.

$$
V=2 t /\left(T_{\mathrm{e} 2}-T_{\mathrm{e} 1}\right)
$$




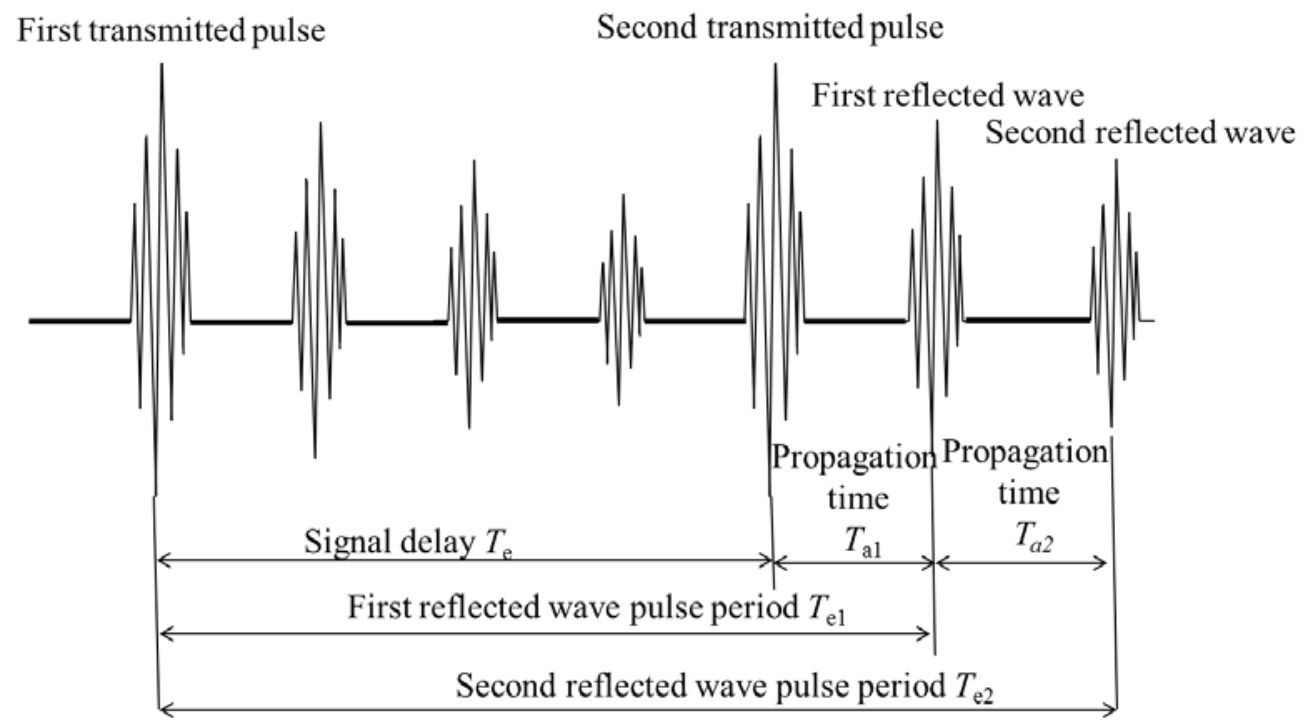

Fig.4 Schematic diagram explaining Sing-Around method. A transmitted pulse is sent to the specimen from an acoustic transducer attached to the upper plate of the specimen. The wave reflected through the specimen is received by the same transducer. After a definite delay time, $T_{\mathrm{e}}$, the next transmitted pulse is sent to the specimen. This operation is repeated with a specified period. The first reflected wave pulse period, $T_{\mathrm{e} 1}$, is obtained by adding $T_{\mathrm{e}}$ to the time required for the first transmitted pulse to propagate through the specimen, $T_{\mathrm{a} 1}$. The second reflected wave pulse period, $T_{\mathrm{e} 2}$, is obtained by adding $T_{\mathrm{e}}$ to the time required for the second transmitted pulse to propagate through the specimen, $T_{\mathrm{a} 2}$. Thus, the velocity, $V$, can be obtained as $V=2 \mathrm{t} /\left(T_{\mathrm{e} 2}-T_{\mathrm{e} 1}\right)$, where $t$ is the thickness of the specimen.

\section{3. 実験結果及び考察}

\section{$3 \cdot 1$ 即時破壊強度}

表 3 は各温度でアニール処理を施した予き裂導入試験片及び平滑試験片の破壊強度を示したものである.いず れも SCG を避けるために約 $455 \mathrm{MPa} / \mathrm{s}$ の高い応力速度で破壊した. SCG とは応力腐食割れによるゆっくりとした き裂成長のことである. なお，ここでは破壊時における曲げ応力 $\sigma_{b}=M_{b} / Z\left(M_{b}\right.$ ：曲げモーメント， $Z$ : 断面係数 $)$ を破壊強度と定義した，比較のためにアニール処理を施していない場合の破壊強度も記している．予き裂導入試 験片については破壞強度の平均值がアニール処理を施すことによりわずかではあるが破壊強度は増加する傾向が あった.アニール処理を施さなかった場合と各アニール温度によるアニール処理を施した場合の破壊強度の平均 值の差に有意さがあるかどうかを判定するために $\mathrm{t}$-検定を行った. 表中の P (Probability) 值は比較する母集団の 間に有意差がない確率を意味しており, その值が $5 \%$ 以上では有意差がないと判断することができる. 表 3 に示 すようにアニール温度 $200^{\circ} \mathrm{C}$ の場合 $45.2 \%$ あったたに対して，アニール温度 $400{ }^{\circ} \mathrm{C}$ 及び $600{ }^{\circ} \mathrm{C}$ の場合はそれ ぞれ $0.8 \% ， 2.4 \%$ でったことより，200 ${ }^{\circ} \mathrm{C}$ のアニール温度ではアニールによる破壊強度への影響はなく $400{ }^{\circ} \mathrm{C}$ 及び $600{ }^{\circ} \mathrm{C}$ のアニール温度では破壊強度はわずかに増加する. 平滑材の破壊強度については, $200{ }^{\circ} \mathrm{C}$ のアニール 温度による破壊強度の平均值はアニールを施したものが施さなかったものよりわずかに下回っているものの, $\mathrm{t}-$ 検定での P 值は大気中 $33.1 \%$, 真空中 $21.9 \%$ と基準值の $5 \%$ をきく上回っており，その有意差はないものとみ なすことができる.したがって, 本材料においては予き裂導入試験片及び平滑試験片のいずれもアニール温度 $200{ }^{\circ} \mathrm{C}$ による破壊強度の低下はなく，アニールを施さない場合とほぼ同一である.

破壊勒性值 $K_{\mathrm{IC}}$ についは高い忘力速度で得られた上記破壞強度を不活性強度とみなし, CSF(Controlled Surface Flaw)法を適用して求めた．すなわち，Newman-Raju（Newman and Raju, 1981）は有限板に半楕円状き裂を有する 応力拡大倸数 $K_{\mathrm{I}}$ として次式を提案している. 


$$
\begin{aligned}
& K_{1}=\sigma_{b} H \sqrt{\frac{\pi a}{Q}} F(a / t, a / c, c / b, \varphi) \\
& Q=1+1.464\left(\frac{a}{c}\right)^{1.65} \quad\left(\frac{a}{c} \leq 1\right)
\end{aligned}
$$

ここで， $\sigma_{b}$ は曲げ応力， $H$ 及び $F$ は曲げに関する境界補正係数， $Q$ はき裂形状の半楕円状き裂に関する第二種

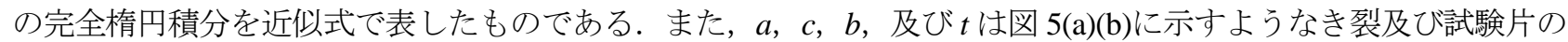
寸法及び形状であり， $\varphi$ は半楕円状き裂の位置を表す離心角である.

式(6)及び式(7)において, 曲げ応力 $\sigma_{\mathrm{b}}$ を曲げ試験で得られた破壊強度に置き換え, き裂寸法 $(c=145 \mu \mathrm{m}, a=120 \mu \mathrm{m})$, 試験片寸法 $(t=4 \mathrm{~mm}, \quad b=1.5 \mathrm{~mm})$ を代入し，離心角 $\varphi=\pi / 2$ とおくことにより表 4 に示すような破壊勒性值 $K_{\mathrm{IC}}$ を求め ることができる. 破壊䩚性值 $K_{\mathrm{IC}}$ も $400{ }^{\circ} \mathrm{C}$ 及び $600{ }^{\circ} \mathrm{C}$ のアニール温度ではわずかではあるが増加する傾向にある.

Table 3 Fracture strength obtained using both pre-cracked and smooth specimens. The P -value in the t-test indicates the probability that there is no significant difference between the mean fracture strength of the

\begin{tabular}{|c|c|c|c|c|c|c|c|}
\hline & \multicolumn{2}{|c|}{ Annealing condition } & $\begin{array}{c}\text { Specimen } \\
\text { number }\end{array}$ & $\begin{array}{c}\text { Mean } \\
\text { fracture strength } \\
(\mathrm{MPa})\end{array}$ & $\begin{array}{c}\text { Standard } \\
\text { deviation } \\
(\mathrm{MPa})\end{array}$ & $\begin{array}{l}\text { Varience } \\
\left(\mathrm{MPa}^{2}\right)\end{array}$ & $\begin{array}{c}\text { P-value } \\
\text { in t-test } \\
(\%)\end{array}$ \\
\hline \multirow{4}{*}{$\begin{array}{c}\text { Precracked } \\
\text { specimen }\end{array}$} & \multicolumn{2}{|c|}{ Without annealing } & 5 & 319 & 13.4 & 143 & \\
\hline & \multirow{3}{*}{$\begin{array}{c}\text { With } \\
\text { annealing }\end{array}$} & $\begin{array}{c}200^{\circ} \mathrm{C}, 100 \mathrm{~h} \\
\text { in vacuum } \\
\end{array}$ & 5 & 326 & 15.4 & 189 & 45.2 \\
\hline & & $\begin{array}{c}400^{\circ} \mathrm{C}, 100 \mathrm{~h} \\
\text { in vacuum }\end{array}$ & 5 & 344 & 8.17 & 53.4 & 0.8 \\
\hline & & $\begin{array}{c}600^{\circ} \mathrm{C}, 100 \mathrm{~h} \\
\text { in vacuum }\end{array}$ & 5 & 341 & 12.2 & 119 & 2.4 \\
\hline \multirow{3}{*}{ Smooth specimen } & \multicolumn{2}{|c|}{ Without annealing } & 5 & 1,270 & 172 & 23,600 & \\
\hline & \multirow{2}{*}{$\begin{array}{c}\text { With } \\
\text { annealing }\end{array}$} & $\begin{array}{c}200^{\circ} \mathrm{C}, 100 \mathrm{~h} \\
\text { in vacuum }\end{array}$ & 5 & 1,140 & 135 & 14,700 & 21.9 \\
\hline & & $\begin{array}{c}200^{\circ} \mathrm{C}, 100 \mathrm{~h} \\
\text { in air }\end{array}$ & 5 & 1,140 & 240 & 45,900 & 33.1 \\
\hline
\end{tabular}
specimen without annealing and that with annealing.

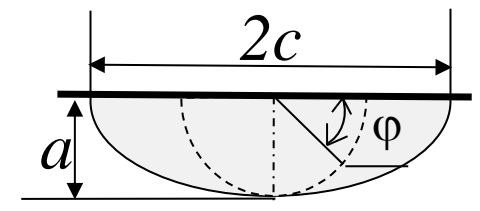

(a)

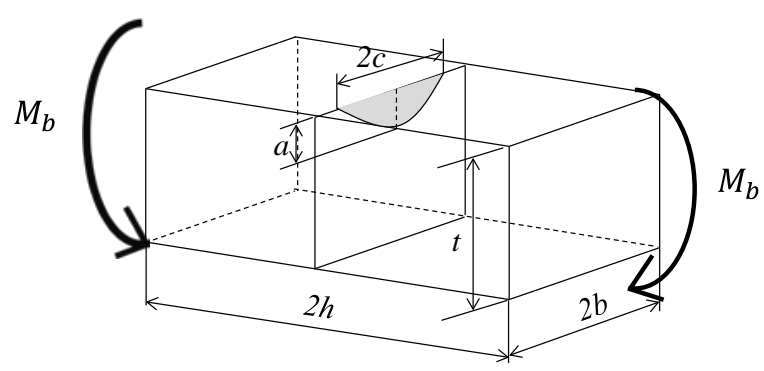

(b)

Fig.5 Schematic diagrams of a surface crack in a finite plate. (a) Crack depth: a, crack length: 2c and parametric angle of a semielliptical surface crack: $\varphi$. (b) Plate thickness: $t$, plate width: $2 b$, and plate length: $2 h$. In Eq. (6), the functions $F$ and $H$ are defined such that the boundary-correction factor for bending is obtained in terms of a/t, a/c, c/b and angular functions, $\varphi$. 
Table 4 Fracture toughness values $K_{\text {IC }}$. These values were obtained by instituting the above fracture strength, shape and dimensions of the indentation flaw into the equation suggested by Newman and Raju (1981).

\begin{tabular}{|c|c|c|c|c|}
\hline & Without & \multicolumn{3}{|c|}{ Annealing temperature } \\
\cline { 3 - 5 } & annealing & $200^{\circ} \mathrm{C}$ & $400^{\circ} \mathrm{C}$ & $600^{\circ} \mathrm{C}$ \\
\hline \hline$K_{\mathrm{IC}}\left(\mathrm{MPa} \cdot \mathrm{m}^{1 / 2}\right)$ & 4.72 & 4.83 & 5.09 & 5.05 \\
\hline
\end{tabular}

\section{$3 \cdot 2$ 静疲労及び繰返し疲労試験}

図 6 は98Nの圧子押込み荷重で予き裂を導入した試験片の静疲労寿命及び繰返し疲労寿命の実験結果を最大負 荷応力と疲労寿命との関係で示したもので，横軸には等価破断時間をとっている．これは，応力が変動する場合 の破断時間を，最大負荷応力が一定に作用すると仮定した場合の破断時間に換算したものであり，両振りによる 繰返し負荷では破断時間をEvans ら（Evans and Fuller，1974）によって提案された換算係数 $g^{-1} \cong(2 \pi n)^{1 / 2}\left\{1+1 /(4 n)+1 /\left(32 n^{2}\right)+\cdots\right\}$ で除すことによって換算することができる. ここで, $n$ は SCG のき 裂進展特性を表寸経験式 $V=V_{0}\left(K_{\mathrm{I}} / K_{\mathrm{IC}}\right)^{n}\left(V\right.$ : き裂進展速度, $K_{\mathrm{I}}$ : 応力拡大係数 $)$ における定数 $V_{0}, n$ の一つであり, 等価時間に換算する際には静疲労試験で得られた $n$ を用いる. 図中には静疲労, 繰返し疲労のいずれも負荷応力 の低下と共に単調に疲労寿命が増加しており, 明確な疲労特性がみられる. 静疲労寿命と繰返し疲労寿命を比較 するならば，いずれの場合も同一の最大負荷応力で繰返し疲労寿命は静疲労寿命より小さく, 負荷応力の低下に よる疲労寿命の増加の割合も繰返し疲労の方が小さいことより, 疲労寿命への応力繰返し効果がみられる. ただ し，これらの繰返し効果は $\mathrm{R}=-1$ の両振り負荷によって行われたものであり，繰返し疲労破断時間を等価破断時 間に換算する際に圧縮応力がき裂進展に寄与しないという仮定のもとで行っている. しかし, 実際の材料にはき 裂面に凹凸があり，き裂面同士の摺り合わせ等で応力遮蔽効果を解消し圧縮応力成分が疲労寿命の低下に寄与寸 ることが考えられる. したがって, 本実験でみられた応力繰返し効果は過大に評価された可能性もある. 疲労特 性に及ぼすアニールの影響についてみるならば，静疲労の場合，ばらつきはあるものの，すべての負荷応力にお いてアニール温度と共に疲労寿命が増加する傾向にあり, 即時破壊強度及び破壞勒性值の傾向に対応するもので ある. 繰返し疲労の場合, 高い負荷応力においてはアニールの影響はほとんどみられないが，低負荷応力側にお いては明確なアニールによる影響がみられる. そこで, 繰返し疲労において最大負荷応力が 85MPa 以下の場合の 疲労寿命に注目する. 図 7 は繰返し疲労において最大負荷応力が 85MPa 以下の場合の実験結果を取り出して示し たものであり, 表 5 は最大負荷応力が 85MPa 以下の場合の繰返し疲労において各熱処理条件下での打ち切り時間 内に破断したものと, 未破断であったものの試験片本数をまとめたものである. $200{ }^{\circ} \mathrm{C}, 400{ }^{\circ} \mathrm{C}$ の変態点以下 の比較的低温でのアニールにおいては, 試験片 12 本中 8 本のものが打ち切り時間以内に破壊せず未破断であった のに対して, アニール処理を施さなかったものは 7 本中 2 本, $600{ }^{\circ} \mathrm{C}$ の高温でアニールしたものは 8 本中 1 本が 未破断であった.これは低温でのアニール処理が繰返し疲労寿命を増大させる効果があったことを意味している. 


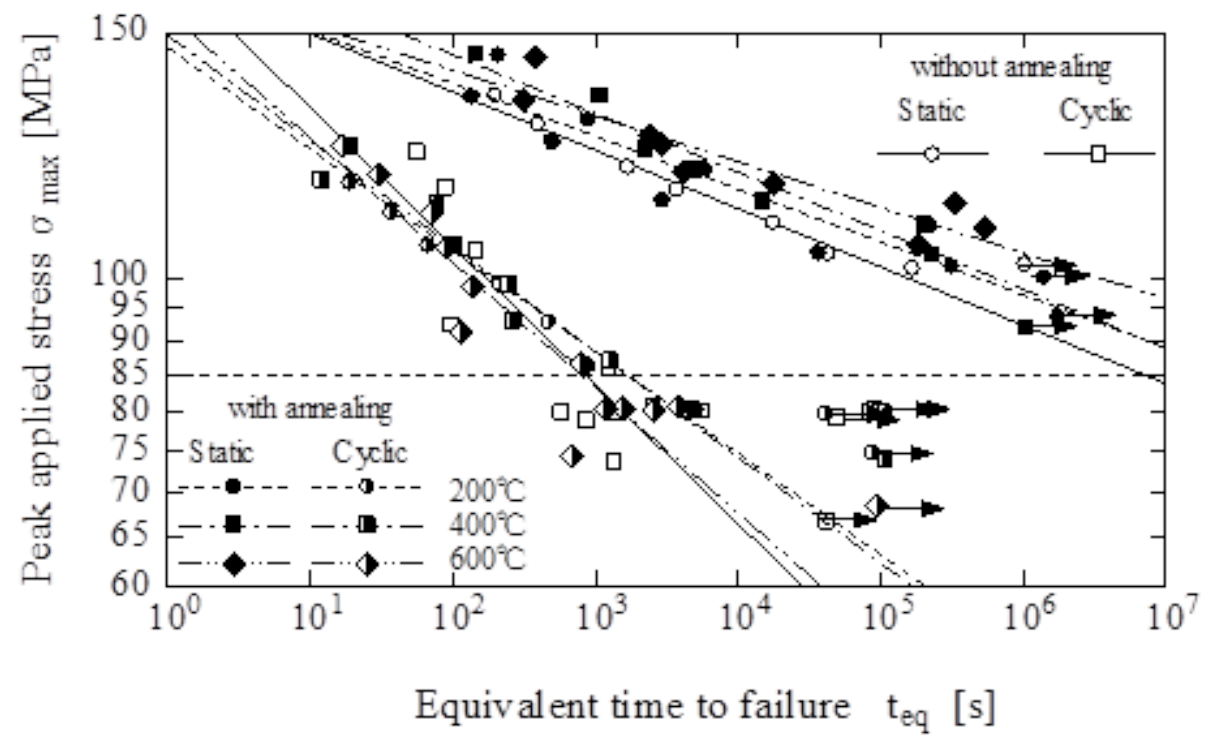

Fig. 6 Static and cyclic fatigue lifetimes as a function of peak applied stress. For the comparison of slow crack growth in static and cyclic fatigue, times-to-failure measurements under cyclic loading were converted into equivalent times-to-failure to predict the time-to-failure under cyclic loading conditions from the static slow crack growth parameters on the assumption that no enhanced effect of cycling on the crack growth occurs. The regression curves are the least squares for the respective data of static and cyclic fatigue at different annealing temperatures. The apparent decrease of the equivalent times-to-failure in cyclic fatigue from the times-to-failure in static fatigue is shown, that is, an enhanced effect of cycling on crack growth occurred. A clear increase in lifetime is observed for heat treatments with annealing temperatures of 200 and $400^{\circ} \mathrm{Cin}$ the case of cyclic fatigue with low applied stress.

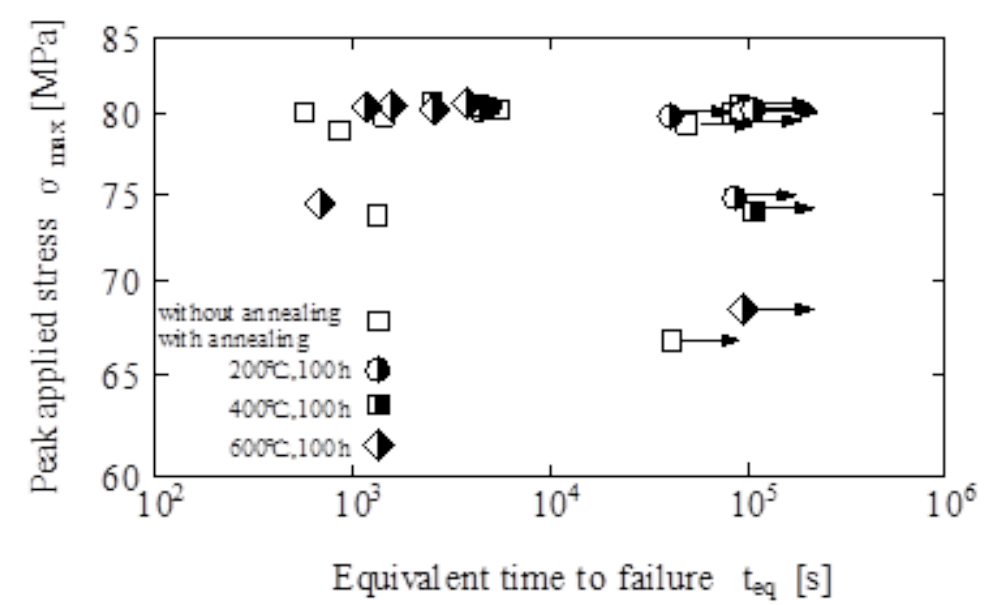

Fig.7 Lifetime data extracted from cyclic fatigue data. The lifetime data in the cyclic loading with a peak applied stress of less than $85 \mathrm{MPa}$ were extracted. There are more specimens not to be broken within the closed time for annealing temperatures of both $200^{\circ} \mathrm{Cand} 400^{\circ} \mathrm{C}$ 
Table 5 Number of specimens broken and not to be broken over the closed time within the specimens peak applied stress is below $85 \mathrm{MPa}$ in cyclic fatigue test.

\begin{tabular}{|c|c|c|c|c|}
\hline & \multirow{2}{*}{$\begin{array}{c}\text { Without } \\
\text { annealing }\end{array}$} & \multicolumn{3}{|c|}{ Annealing temperature } \\
\cline { 3 - 5 } & 5 & $200^{\circ} \mathrm{C}$ & $400^{\circ} \mathrm{C}$ & $600^{\circ} \mathrm{C}$ \\
\hline \hline $\begin{array}{c}\text { No. of specimens } \\
\text { broken }\end{array}$ & 5 & 2 & 7 \\
\hline $\begin{array}{c}\text { No. of specimens } \\
\text { not to be broken }\end{array}$ & 2 & 4 & 4 & 1 \\
\hline
\end{tabular}

\section{$3 \cdot 3 \quad K_{I}-V$ 線図}

図 8 は図 6 の疲労試験で得られた最大負荷応力と疲労寿命との関係を，T.Fett と D.Munz（Fett and Munz, 1985） によって提案された次式を用いることにより初期応力拡大係数 $K_{I i}$ とき裂進展速度 $V(=\mathrm{d} a / \mathrm{d} t)$ との関係に変換し, き裂進展特性を比較したものである。

$$
\begin{aligned}
& V\left(K_{I i}\right)=-\frac{2 K_{I i}^{2}}{Y^{2} \sigma_{\text {max }}{ }^{2} t_{e q}} \frac{d\left(\ln K_{I i}\right)}{d\left(\ln t_{e q}\right)} \\
& \text { ここで, } \\
& K_{I i}=Y \sigma_{\max } \sqrt{a_{i}}
\end{aligned}
$$

ここで， $a_{i}$ は初期き裂深さ，Yは Newman-Raju（Newman and Raju, 1981）の式より求めた形状係数である.

同一応力拡大係数 $K_{I i}$ に対するき裂進展速度 $V$ は, 繰返し疲労の場合のように動的負荷が加わった場合の方が, 静疲労のような静的負荷が加わった場合よりも明らかに速く, この傾向は特に $K_{I i}$ 值の小さな領域で顕著であるこ とがわかる．また，アニール温度の影響についてみるならば，静疲労の場合，ばらつきの範囲内でき裂進展速度

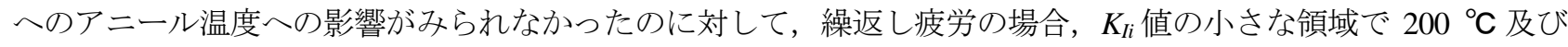
$400{ }^{\circ} \mathrm{C}$ で $100 \mathrm{hr}$ アニールした場合に明確なき裂進展速度の低下がみられる。これは変態点以下のアニール処理を 施すことによって SCG によるき裂の進展が抑制されたことを示している. 


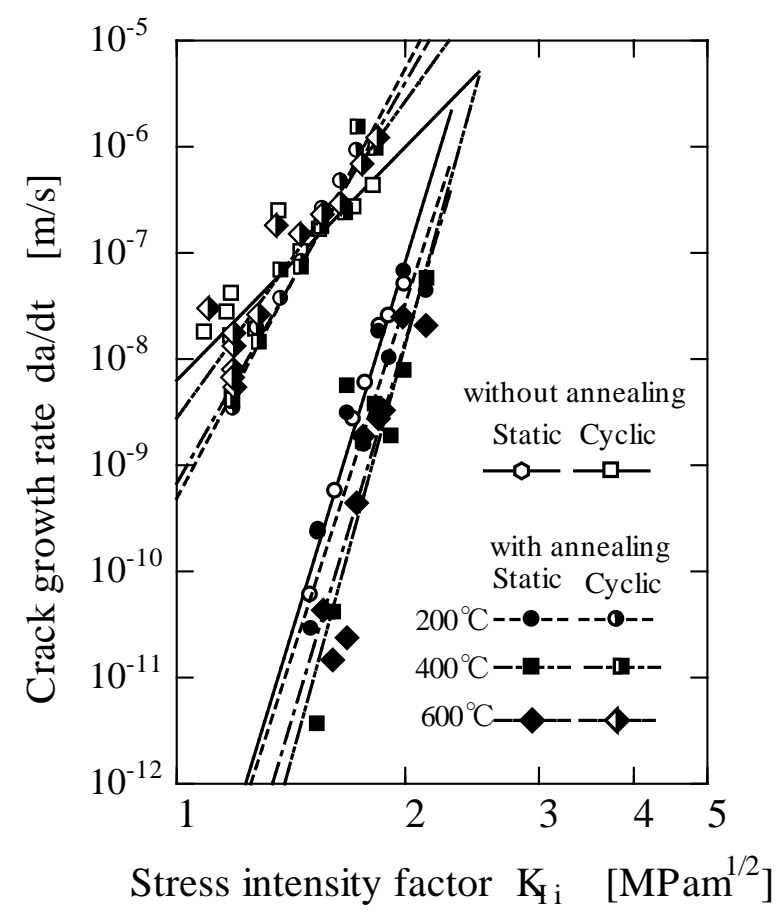

Fig. 8 Plot of $d a / d t$ vs $K_{I i}$ evaluated from the lifetime measurements shown in Fig.6. The procedure for the evaluation of crack growth rates from life time measurements was proposed by T.Fett and D.Munz (Fett and Munz, 1985). Crack growth rate $V(=d a / d t)$ can be obtained by using eq. (8) from the relation between peak applied stress, $\sigma_{\max }$, and equivalent time-to-failure, $t_{e q}$. In any heat treatment the crack growth rate, $d a / d t$, under cyclic loading is obviously larger than that under static loading at the same initial stress intensity factor, $K_{\mathrm{li}}$, and the tendency is more remarkable at the low stress intensity factor. Furthermore, at the low stress intensity factor under cyclic loading, the crack growth rate of the specimen with heat treatment at the annealing temperatures of 200 or $400^{\circ} \mathrm{Cis}$ clearly lower than that without annealing or that with heat treatment at the annealing temperature of $600^{\circ} \mathrm{C}$

\section{$3 \cdot 4 \mathrm{X}$ 線回折法及び超音波による相変態の検討}

\section{$3 \cdot 4 \cdot 1 \mathrm{X}$ 線回折結果}

図 9 は各温度でアニール処理を施した場合のX 線回折結果を示したものであり図 9(a) (d)は繰返し疲労試験前, 図 9(e) (h)は繰返し疲労試験後に測定したものである.ここでは, 単斜晶の回折ピークが現れる $2 \theta=25^{\circ}$ から $2 \theta=40^{\circ}$ の領域の回折パターンを示す．なお，縦軸は最大ピークが現れる $2 \theta=30^{\circ}$ 付近（正方晶（111）面）の X 線強度を

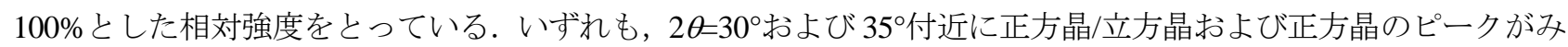
られる. 単斜晶が析出した場合 $2 \theta=28^{\circ}$ 付近に回折ピークが現れるのでそこに注目する. まず, 疲労試験前の試験 片において, 図 9(b)の $200{ }^{\circ} \mathrm{C}$ のアニールを施した場合は図 9(a)の熱処理を施さなかった場合と比較して明らかに 明瞭なピークが現れてくることがわかる. 図 9(c)の $400{ }^{\circ} \mathrm{C}$ のアニール温度ではそのピークはほぼその大きさを維 持するが，図 9(d)の $600{ }^{\circ} \mathrm{C}$ のアニールでは大きく低下し，熱処理を施さなかった場合とほぼ同程度となる. これ は, $200{ }^{\circ} \mathrm{C}, 400{ }^{\circ} \mathrm{C}$ の低温でアニールした場合は正方晶から単斜晶への相変態が生じるが， $600{ }^{\circ} \mathrm{C}$ の高温でアニ 一ルした場合は相変態を起こす割合が大きく減少することを意味している．図 9(e) (h)の繰返し疲労試験後にお いても繰返し疲労試験前とほぼ同様な傾向がみられた. 定量的評価を行うため, 単斜晶のピークが現れる $2 \theta=28^{\circ}$ 付近の相対強度を比較したものを図 10 に示寸.疲労試験前と疲労試験後に現れるピークの相対強度の大きさは同 程度であり，いずれもアニール温度 $200{ }^{\circ} \mathrm{C}$ で相対強度は最大となり, $400{ }^{\circ} \mathrm{C}, 600{ }^{\circ} \mathrm{C}$ の順に減少する傾向がみら れる. これは応力誘起による相変態はき裂近傍に限られるため, 本測定方法ではそれを検出することが困難であ ったことによるものと考える. 


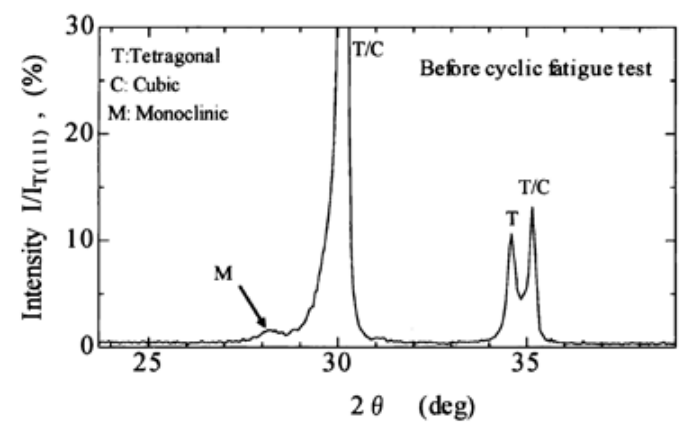

(a) Without annealing

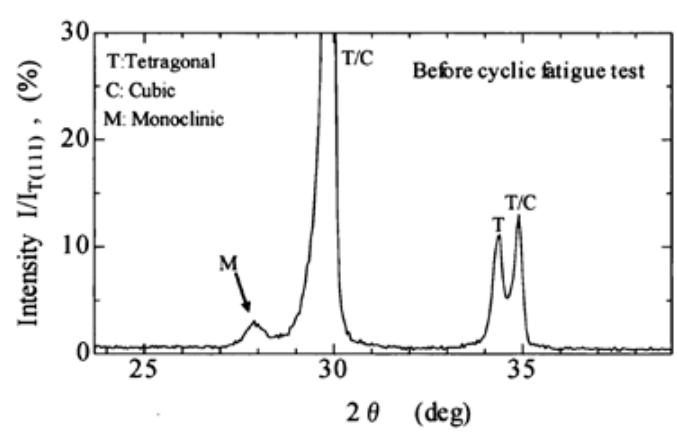

(b) $200^{\circ} \mathrm{C}, 100 \mathrm{~h}$ in vacuum

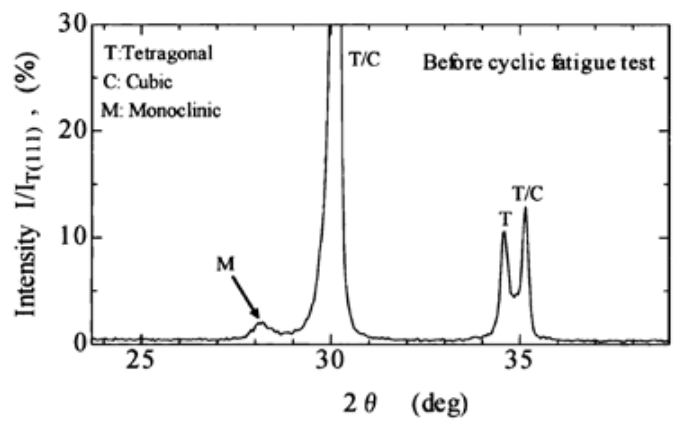

(c) $400^{\circ} \mathrm{C}, 100 \mathrm{~h}$ in vacuum

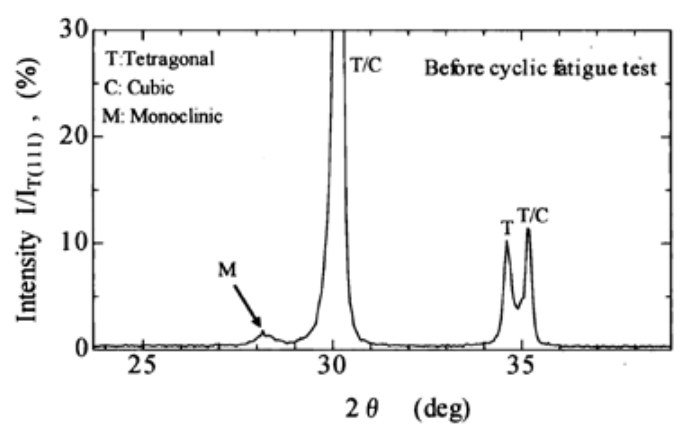

(d) $600^{\circ} \mathrm{C}, 100 \mathrm{~h}$ in vacuum

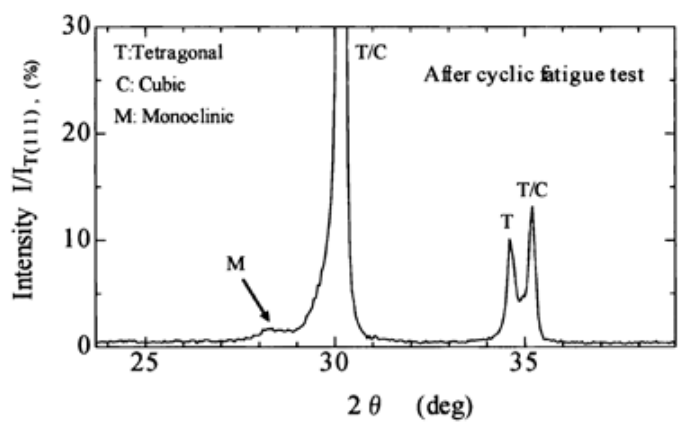

(e) Without annealing

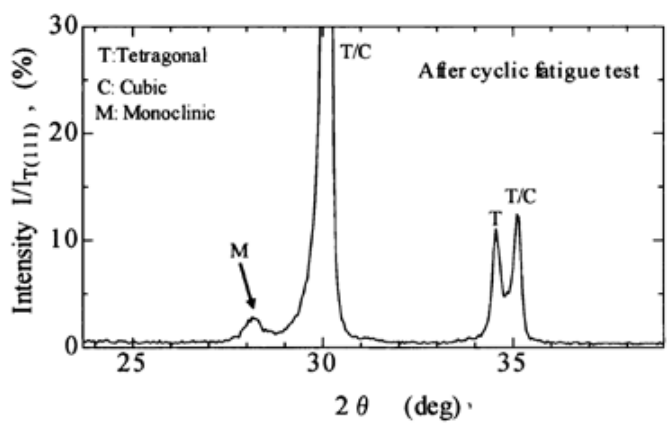

(f) $200^{\circ} \mathrm{C}, 100 \mathrm{~h}$ in vacuum

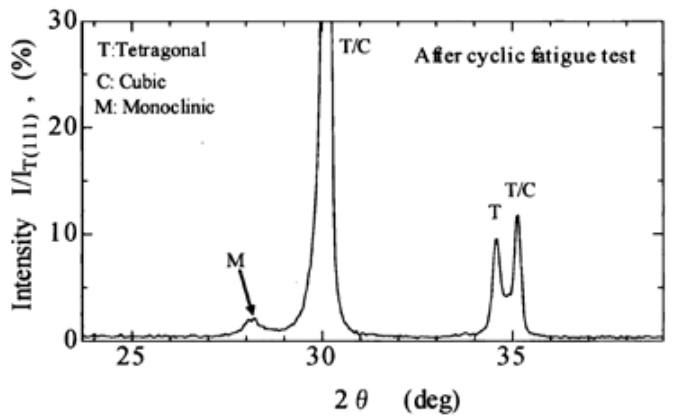

(g) $400^{\circ} \mathrm{C}, 100 \mathrm{~h}$ in vacuum

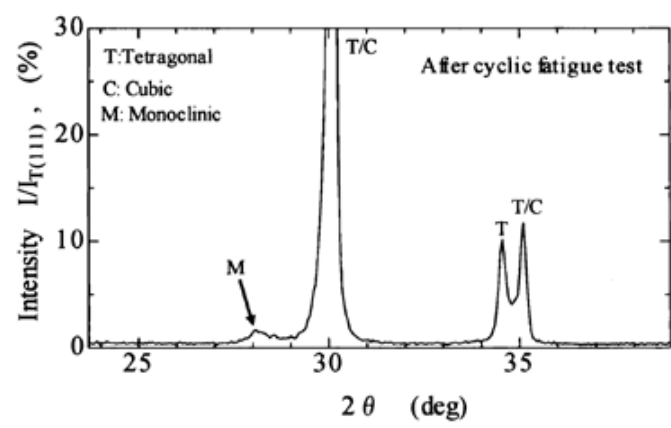

(h) $600^{\circ} \mathrm{C}, 100 \mathrm{~h}$ in vacuum

Fig. 9 X-ray powder diffraction results for specimens annealed at various temperatures (a) to (d) before cyclic fatigue testing and (e) to (h) after cyclic fatigue testing. There were no significant differences between XRD results obtained before cyclic fatigue testing and after the fatigue testing. For example, the peak intensities were mainly observed at $2 \theta=30^{\circ}$, and before and after $35^{\circ}$ corresponding to tetragonal and/or cubic phases and a tetragonal phase. The peak intensities at $2 \theta=28^{\circ}$ corresponded to a monotonic phase, which was clearly observed in the specimens annealed at both 200 and $400^{\circ} \mathrm{Cin}$ a vacuum, although the peak was not clear in both the specimen without annealing and the specimen annealed $600^{\circ} \mathrm{C}$ for $100 \mathrm{~h}$ in a vacuum. Therefore, we assume that phase transformation from tetragonal to monoclinic was caused by low-temperature annealing. 


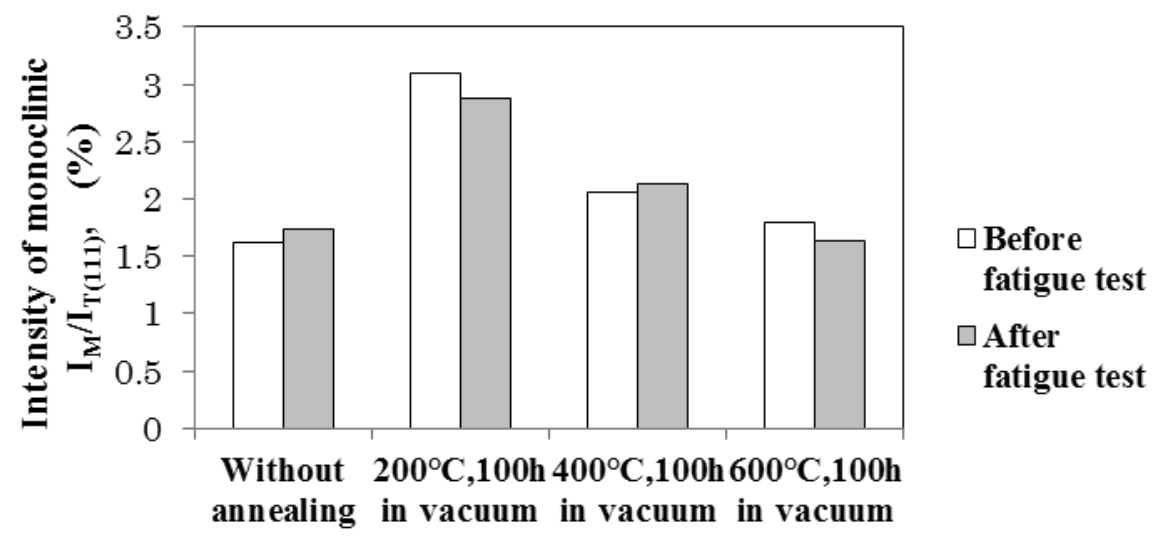

Annealing condition

Fig.10 Monoclinic peak intensity before cyclic fatigue testing and after cyclic fatigue testing. There were no significant differences between their peak intensities before cyclic fatigue testing after cyclic fatigue testing.

\section{$3 \cdot 4 \cdot 2$ 超音波音弾性法}

一般的に材料の弾性変形は近似的に線形とみなされ，単軸負荷を加えた場合の軸方向応力 $\sigma_{a}$ と軸方向ひずみ $\varepsilon_{a}$ との関係は $\sigma_{a}=E \varepsilon_{a}(\mathrm{E}:$ ヤング率)のような一次関数で表すことができる. しかし厳密には極くわずかの非線形性が 認められており，金属材料の場合，その非線形性は変形と共に発生する可動転位に起因することが知られており

（金持他，1976）（金持他，1978），第二相粒子等の材料の不均一性が非線形性の増大を引き起こすことが考えら れる. 本材料は微細な正方晶ジルコニア結晶粒からなる均一なセラミック材料であり，非線形性は小さいと考え られる。しかしながら，アニール処理を施すことにより各所に単斜晶が析出するならば，正方晶と単斜晶との境 界領域に圧縮応力及びマイクロクラックが発生し，それらが弾性変形の非線形性を増大させることは十分考えら れる. 以上の観点から, 超音波的手法により導出した高次の弾性定数により弾性変形を非線形表示し, 非線形性 とアニール温度との関係を調べることにより，アニールによる相変態発生の有無について検討する.

非線形弾性論によれば，単軸応力 $\sigma_{11}$ と単軸ひずみ $\varepsilon_{11}$ との間には近似的に次式の関係があることが知られてい る（福岡，岩清水，他，1994）.

$$
\sigma_{11}=(\lambda+2 \mu-2 v \lambda) \varepsilon_{11}+\frac{1}{2}\left\{(2 v-1)^{2} v_{1}+2\left(3-4 v+2 v^{2}\right) v_{2}+8 v_{3}\right\} \varepsilon_{11}{ }^{2}
$$

ここでれ及び $\mu$ は二次の弾性定数 (ラーメの定数)， $v_{1}, v_{2}$, 及び $v_{3}$ は三次の弾性定数であり, $v$ はポアソン比である. 式(10)に掠いて, $\varepsilon_{11}$ の1次の項の係数を

$$
\lambda+2 \mu-2 v \lambda=E
$$

$\varepsilon_{11}$ の 2 次の項の係数を

$$
\frac{1}{2}\left\{(2 v-1)^{2} v_{1}+2\left(3-4 v+2 v^{2}\right) v_{2}+8 v_{3}\right\}=E^{\prime}
$$

とおき, 単軸応力 $\sigma_{11}=-\sigma_{a}\left(\sigma_{a}:\right.$ 軸方向圧縮応力 $), \varepsilon_{11}=-\varepsilon_{a}\left(\varepsilon_{a}:\right.$ 軸方向圧縮ひずみ $)$ とおくならば,

$$
\sigma_{a}=E \varepsilon_{a}-E^{\prime} \varepsilon_{a}{ }^{2}
$$

として， $\varepsilon_{\mathrm{a}}$ に関する二次関数で表すことができる．また，式(13)の第 1 項目は線形性，第 2 項目は線形性からの ずれであり，Eは非線形性を表すパラメータとみなすことができる.

表 6 に 2 ・ 4 節の音弾性法に求めた三次の弾性定数 $v_{1}, v_{2}, v_{3}$ ，それらを式(12)に代入することによって得られ た $E^{\prime}$ を示す. 表中には二次の弾性定数 $\lambda, \mu, v$ を式(11)に代入することによって得られたヤング率 $E$ も示してあ る. 二次の弾性定数にはほとんど熱処理による影響がみられず, それから得られるヤング率 $E$ およびポアソン比 $v$ もほぼ一定であるのに対して, 三次の弾性定数 $v_{1}, v_{2}, v_{3}$ では明らかに差があり, 熱処理によって材料の弾 
性変形に非線形性が生じることが伺われる．図 11 は非線形性の程度を表す $E$ のアニール温度の影響を示したも のである. $200{ }^{\circ} \mathrm{C}$ のアニール温度で $E^{\prime}$ は増加するが， $400{ }^{\circ} \mathrm{C}, 600{ }^{\circ} \mathrm{C}$ とアニール温度が高くなるにつれて $E^{\prime}$ は 減少する。これらの傾向は $200{ }^{\circ} \mathrm{C}$ およ゙ $400{ }^{\circ} \mathrm{C}$ の変態点以下の低温でアニールした場合に相変態が起り単斜晶 が析出するが, $600{ }^{\circ} \mathrm{C}$ の高温ではその析出が減少したことを示している.

Table 6 "Second-order” and “ Third-order” elastic constants obtained from the method of stress analysis with ultrasonic waves. The "Third-order" elastic constants of the material were determined by measuring the change of ultrasonic velocities in elastic material with stress applied to materials.

\begin{tabular}{|c|c|c|c|c|c|c|c|c|}
\hline \multirow{2}{*}{ Heat treatment } & \multicolumn{3}{|c|}{ Second order elastic constant (GPa) } & \multicolumn{4}{c|}{ Third order elastic constant (GPa) } \\
\cline { 2 - 9 } & $\lambda$ & $\mu$ & $v$ & $\mathrm{E}$ & $v_{1}$ & $v_{2}$ & $v_{3}$ & $\mathrm{E}^{\prime}$ \\
\hline without heat treatment & 299 & 82 & 0.39 & 228 & 13900 & -399 & 111.4 & 85 \\
\hline $200^{\circ} \mathrm{C} \times 100 \mathrm{~h}$ in vacuum & 302 & 82 & 0.39 & 229 & 17600 & -235 & 191 & 781 \\
\hline $400^{\circ} \mathrm{C} \times 100 \mathrm{~h}$ in vacuum & 296 & 82 & 0.39 & 228 & 15500 & -296 & 161.4 & 505 \\
\hline $600^{\circ} \mathrm{C} \times 100 \mathrm{~h}$ in vacuum & 300 & 82 & 0.39 & 228 & 12500 & -525 & 180.1 & 106 \\
\hline
\end{tabular}

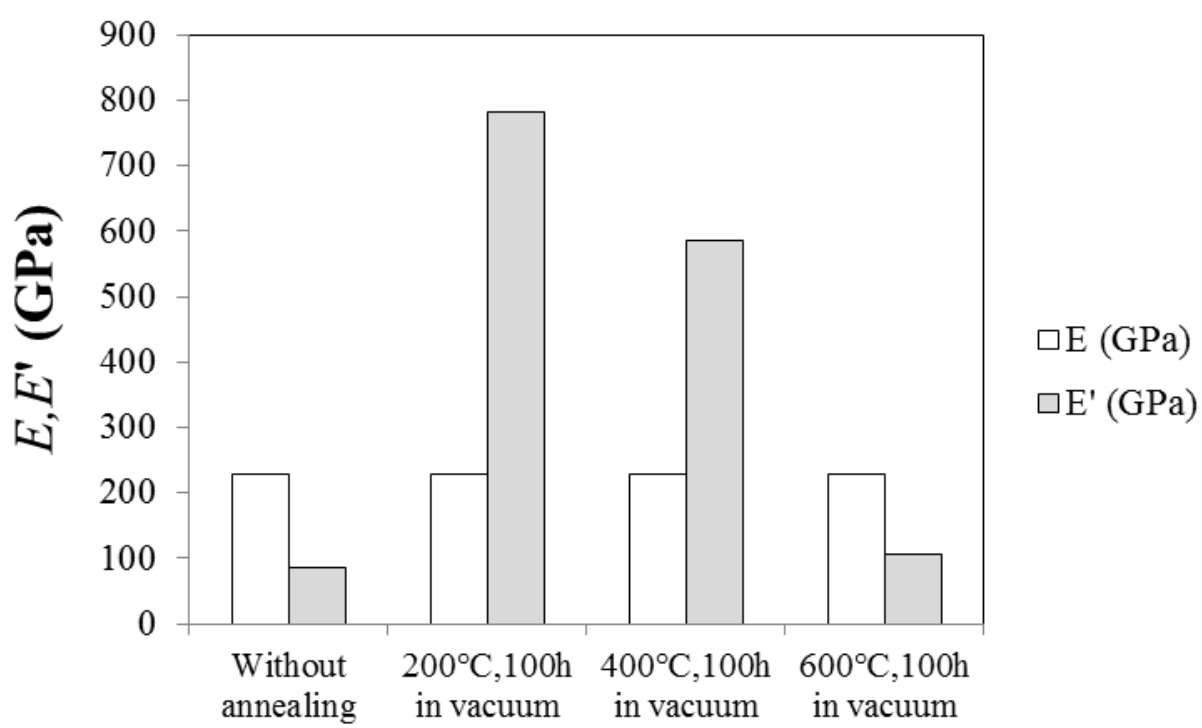

Fig.11 Variations in the second-order elastic constant, $E$, and the third-order elastic constant, $E$ ', according to annealing temperature. Note that the $E$ was constant throughout the range of annealing temperatures considered herein. On the other hand, for an annealing temperature of $200^{\circ} \mathrm{C} E^{\prime}$, is clearly higher than in the case without annealing. However, $E^{\prime}$, decreased from 200 to $600^{\circ} \mathrm{C}$, indicating that the non-linearity of the stress- strain curve for specimen annealed at both $200^{\circ} \mathrm{C}$ and $400^{\circ} \mathrm{C}$ was higher than that for the specimen without annealing.

\section{$3 \cdot 5$ SEM 観察}

図 12(a) (d)は熱処理を施さなかった場合と $200{ }^{\circ} \mathrm{C} ， 100 \mathrm{~h}$ のアニール処理を施した場合の試験片について繰返 し疲労により破壞した破面の SEM を示したものである。いずれも全体に粒界割れの様相を示したが，熱処理を 施さなかった場合の破面は平坦であるのに対して，アニール処理を施した場合は凹凸の程度が大きく，各所に結 晶粒が抜け落ちたような痕跡が見られた。これは，アニールを施すことにより析出した単斜晶と基地組織との界 面にマイクロクラックが多数発生し，そこが剥離しやすくなったため，それらの界面を迂回してき裂が進展した ことによるものと考える.このようなき裂の迁回は $R$ 曲線の上昇を示唆するものである. 


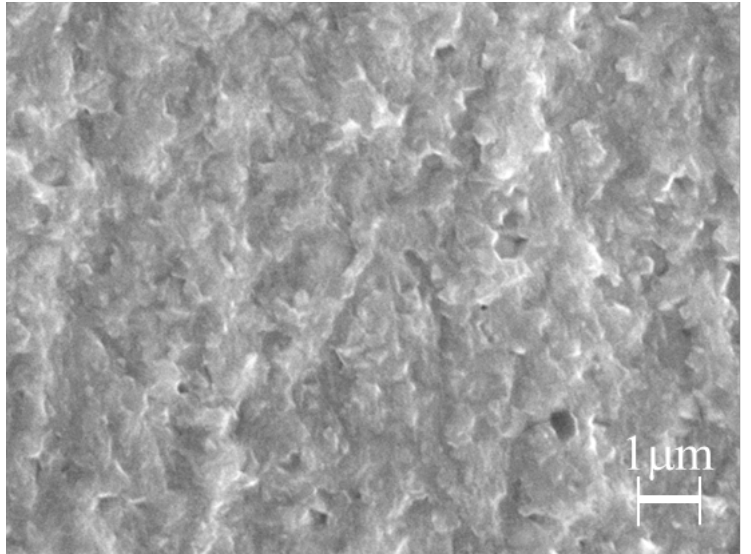

(a) Without annealing

Peak applied stress $=80.2 \mathrm{MPa}$

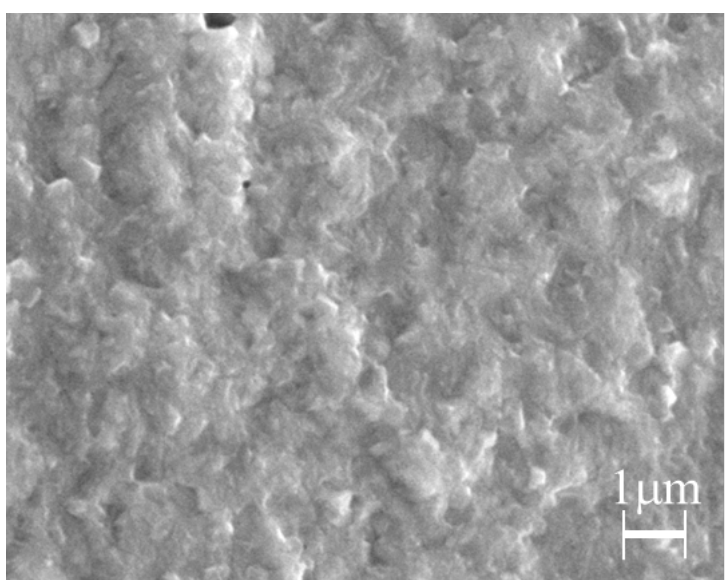

(b) Without annealing

Peak applied stress $=80.0 \mathrm{MPa}$

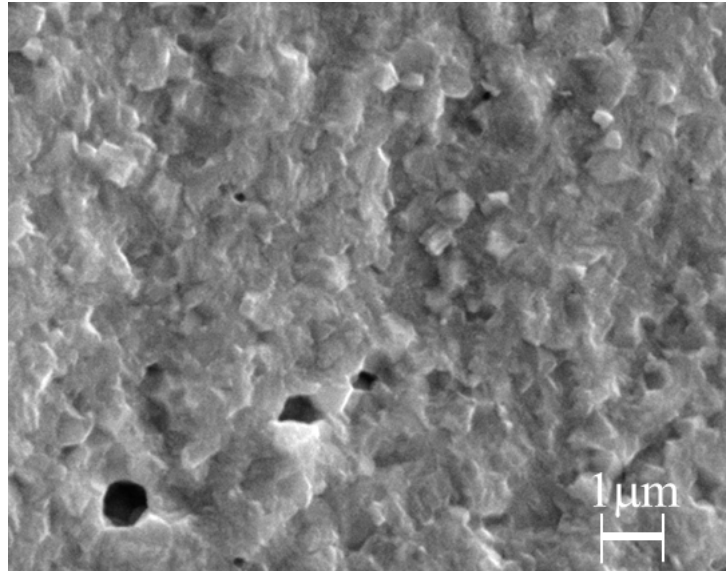

(c) Annealed at $200^{\circ} \mathrm{C}$ for $100 \mathrm{~h}$ in vacuum Peak applied stress $=80.0 \mathrm{MPa}$

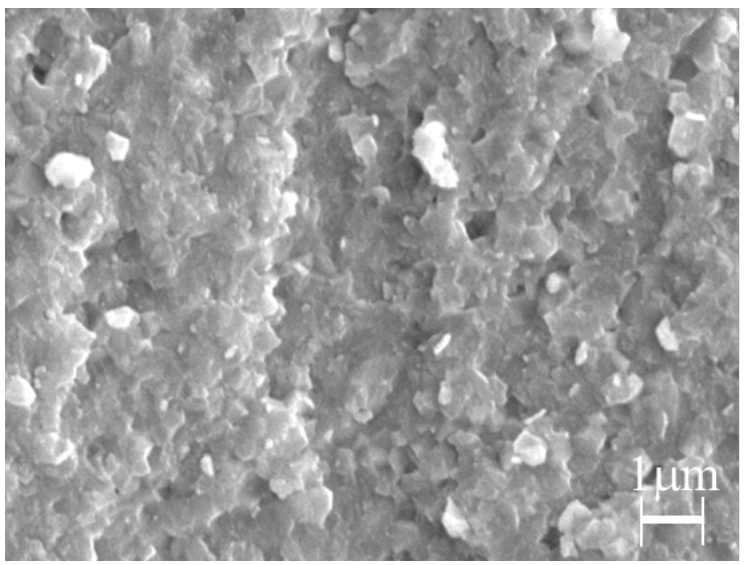

(d) Annealed at $200^{\circ} \mathrm{Cfor} 100 \mathrm{~h}$ in vacuum Peak applied stress $=86.4 \mathrm{MPa}$

Fig. 12 Scanning electron microscope fractograph of specimens fractured by cycle fatigue. (a) and (b)Specimens without annealing, and(c) and (d) Specimens annealed at $200^{\circ} \mathrm{Cfor} 100 \mathrm{~h}$ in a vacuum. In all specimens, the fracture mode was intergranular cracking, but the fracture surfaces of the specimen without annealed surfaces were flat. In contrast, the fracture surfaces of the specimens annealed at $20^{\circ} \mathrm{Cfor} 100 \mathrm{~h}$ in vacuum were rough and some grains appeared to be got rid of the surfaces. The fractograph shows that the crack propagates in a zig-zag fashion in the specimens annealed at $200^{\circ} \mathrm{C}$

\section{$3 \cdot 6 \quad R$ 曲線による絽返し疲労寿命増加のメカニズム}

ジルコニアの $R$ 曲線にはき裂進展抵抗の増加が主に正方晶から単斜晶に変態寸るときの体積膨張による変態強 化型とマイクロクラックの発生によるとするマイクロクラック型の二つのタイプがある（Swain and Hannink, 1984）(堀，1990)が知られている. 本節では低温アニールによる低応力下での寿命増加のメカニズムを $R$ 曲線を 用いて説明する. 図 13 は縦軸に $K_{\mathrm{R}}^{2}$, 横軸にき裂進展長さ $\Delta \mathrm{c}$ をとって静疲労, 繰返し疲労におけるき裂進展の過 程を模式的に示したものである.アニール処理を施していない試験片の静疲労の場合は(1に示すようにき裂先端 にプロセスゾーンを形成し変態強化型 $R$ 曲線にそって進展するが， $R$ 曲線の上昇勾配が大きいためき裂の進展速 度は緩慢であり，応力拡大係数 $K$ が $K_{1 \mathrm{R}}$ を上回る時点で不安定破壊を起こす，一方，アニール処理を施していな い試験片の繰返し疲労の場合は(2)に示すように繰返し負荷によってき裂進展初期においてプロセスゾーンにマイ クロクラックが発生し変態強化型からマイクロクラック強化型 $R$ 曲線に遷移寸る. き裂はマイクロクラック強化 
型 $R$ 曲線にそってき裂は進展する，その際，主き裂とマイクロクラックとの連結・合体によりき裂進展量が増大 すると共にき裂進展駆動力 $K$ も増大寸る. 一方き裂進展抵抗 $K_{\mathrm{R}}$ はマイクロクラック強化型になるため大きく低 下寸る. それによりき裂進展速度が増大し， $\Delta c_{\mathrm{C} 2}$ のように大きくき裂が進展した後， $K=K_{2 \mathrm{R}}$ を満足する点で不 安定破壊する. $200{ }^{\circ} \mathrm{C}$ あいは $400^{\circ} \mathrm{C}$ のアニール処理を施した場合はき裂進展後方に, より多数のマイクロクラ ックを有する厚いプロセスゾーンを形成し $R$ 曲線が(3)に示すように上昇する．き裂長さ $c=c_{0}+\Delta c_{\mathrm{c} 2}$ の時点ではま だ不安定点に到達しておらずさらに $c=c_{0}+\Delta c_{\mathrm{c} 3}$ までき裂が進展したときに $K=K_{3 \mathrm{R}}$ となり不安定破壊する. $\mathrm{c}_{0}+\Delta \mathrm{c}_{\mathrm{c} 2}$ から $\mathrm{C}_{0}+\Delta \mathrm{c}_{\mathrm{C} 3}$ までき裂が進展する際, き裂進展抵抗は $K_{2 \mathrm{R}}$ から $K_{3 \mathrm{R}}$ まで急激に増大寸るため, き裂の進展がそこで 停留し長寿命化するものと考える，なお，アニール処理を施した場合の $R$ 曲線の上昇は前節の SEM 観察におい て，き裂が迁回して進展した痕跡があるという事実に対応するものである.

$$
K_{1 R}^{2}=Y^{2} \cdot \sigma_{s}^{2}\left(c_{0}+\Delta c_{s 1}\right)
$$

(Without annealing, static fatigue)

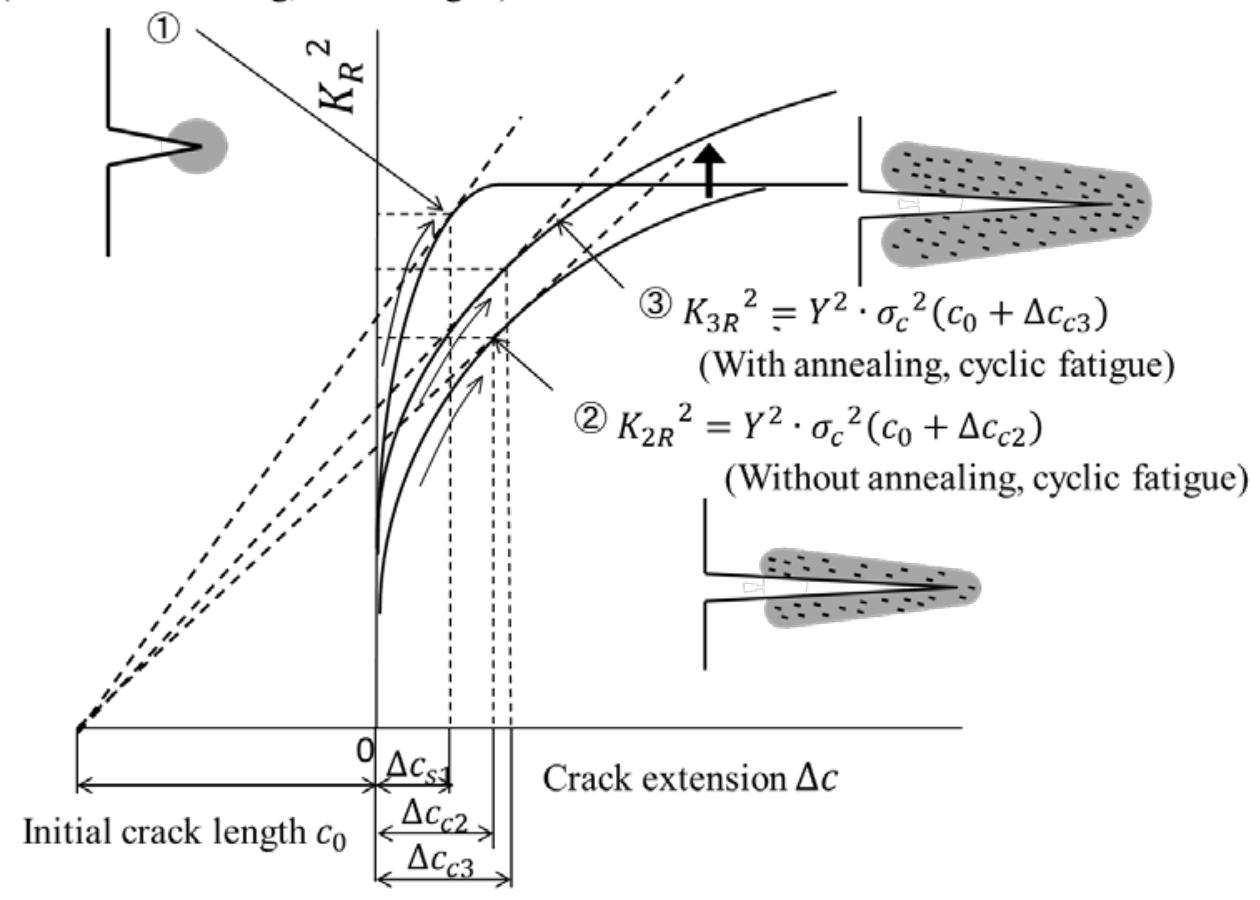

Fig.13 Schematic representation showing slow crack growth in static and cyclic fatigue. In static fatigue a crack grows along the transformation toughening type $R$-curve. The crack resistance increases quickly, and the crack growth rate decreases with crack extension, and fractures occur with small crack extension. On the other hand, in cyclic fatigue, a crack grows along the micro-cracking toughening type $R$-curve. The crack resistance decreases due to the change of the $R$-curve, and the crack growth rate increases with crack tension, and unstable fractures occur at $c=c_{0}+\Delta c_{2}$. Furthermore, by applying annealing, the process zone becomes enlarged and the $R$-curve is raised as shown. From point (2) to unstable point (3) the crack resistance $K_{\mathrm{R}}$ increases abruptly from $K_{2 \mathrm{R}}$ to $K_{3 \mathrm{R}}$, so the crack is arrested and the fatigue life time is extended.

\section{4. 結 言}

繰返し応力下での疲労寿命低下抑制対策として，真空中でアニール処理を施し，負荷が加わる前に正方晶の一 部を予め単斜晶に相変態させ，負荷が作用した際に応力誘起変態によって形成されるプロセスゾーンの領域を拡 大させることにより，き裂進展抵抗を増大させることを考えた．具体的には真空䨌囲気中で設定温度 $\left(200{ }^{\circ} \mathrm{C}\right.$, $400{ }^{\circ} \mathrm{C}, 600{ }^{\circ} \mathrm{C}$ の 3 段階) に昇温し，100 時間一定温度に保持することによりアニール処理を施した試験片に対 して．静疲労及び繰返し疲労試験を行い，疲労特性に及ぼすアニールの影響について調べると共に，疲労寿命低 下抑制の立場から最適なアニール条件を検討した。 
（1）破壊勒性值 $K_{\mathrm{IC}}$ を CSF 法で求めたところ，アニール処理を施さない場合は $4.72 \mathrm{MPam}^{1 / 2}$ であったが，400 ${ }^{\circ} \mathrm{C}$ 及び $600{ }^{\circ} \mathrm{C}$ のアニール温度でアニール処理を施すことにより $5.09 \mathrm{MPam}^{1 / 2}$ まで増加した.

（2）同一負荷応力において静疲労寿命と繰返し疲労寿命とを比較したところ，アニール処理を施した材料にお いても明確な応力繰返し効果すなわち繰返し応力による疲労寿命低下が認められた.

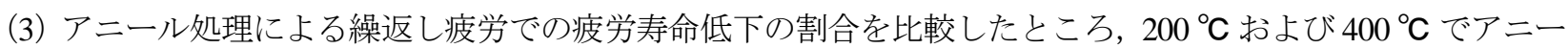

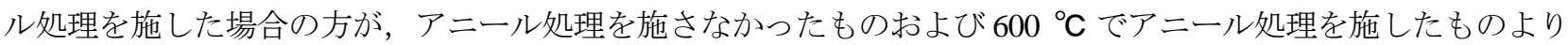
もその低下の割合が小さいことがわかった。

（4）低応力下での繰返し疲労試験において打ち切り時間内に未破断であった試験片本数を比較したところ,

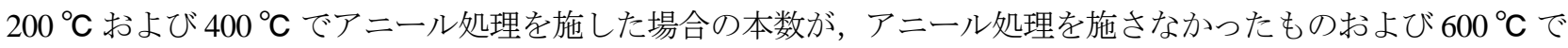

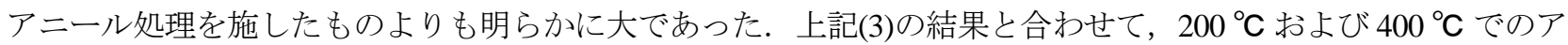
ニール処理が繰返し応力による疲労寿命の低下を抑制するのに効果があることがわかった.

（5）繰返し疲労試験前及び繰返し疲労試験後の試験片に対して X 線回折を行い，アニール処理における温度の 影響を調べたところ,いずれの場合もアニール処理を施さなかった場合には単斜晶の析出を表す回折ピークがほ とんどみられなかったのに対して，200 으゙は明瞭な回折ピークがみられた。 しかし，400 ${ }^{\circ} \mathrm{C}, 600{ }^{\circ} \mathrm{C}$ と温度 が上昇するにつれて回折ピークはしだいに減少した。

(6) 繰返し疲労試験を行っていない試験片に対して超音波を用いた音弾性測定法により三次の弾性定数を求め, アニール処理による弾性変形の非線形性を調べたところ，200 ${ }^{\circ} \mathrm{C}$ でアニール処理を施したものはアニール処理 を施さなかったものよりも明らかに非線形性が大であった。しかし，400 ${ }^{\circ} \mathrm{C} ， 600{ }^{\circ} \mathrm{C}$ と温度が上昇するにつれ てその非線形性はしだいに減少した。

（7）上記 X 線回折及び超音波音弾性法により，真空中で $200{ }^{\circ} \mathrm{C}$ あいは $400{ }^{\circ} \mathrm{C}$ の低温アニール処理を施すこ とによって，正方晶中に単斜晶が析出することを確認することができた.

（8）アニール処理を施さない場合と $200{ }^{\circ} \mathrm{C}$ のアニール処理をお施した場合について SEMによる破面観察を行 ったところ，いずれも全体に粒界割れの様相を示したが，熱処理を施さなかった場合の破面は平坦であるのに対 して,アニール処理を施した場合は凹凹の程度が大きく, 各所に結晶粒が抜け落ちたような痕跡が見られた。こ れは，アニールを施すことにより析出した単斜晶と基地組織との界面にマイクロクラックが多数発生し，そこが 剥離しやすくなったため，それらの界面を迁回してき裂が進展したことによるものと考えた.

（9）低温アニール処理の繰返し疲労寿命低下抑制効果は熱誘起による相変態によって正方晶中に析出する単斜 晶が, 繰返し応力下でき裂の周囲で形成される多数のマイクロクラックを有するプロセスゾーンを拡大し，き裂 の進展抵抗を増大させたためであると考えた.

\section{文献}

Claussen, N., Science and technology of zirconia II, The American Ceramic Society in Advances in Ceramics Edited by Claussen, N., Ruhle, M. and Heuer, A.H. (1984), pp.325-351.

Evans, A.G, and Fuller, O.R., Crack propagation in ceramic materials under cyclic loading conditions, Metallurgical Transactions, Vol.5(1974), pp.1-33.

Fett, T. and Munz, D., Determination of v-K $\mathrm{K}_{\mathrm{I}}$ curves by a modified evaluation of lifetime measurements in static bending tests , Journal of the American Ceramic Societies,Vol.68, No.8(1985), pp.C-213-C-215.

堀 三郎, 強靭ジルコニア タフなセラミックス(1990), pp.47-49, 内田老鶴圃.

福岡秀和，音弾性 音弾性理論の基礎 (1994), pp.2-18, 日本非破壊検查協会.

岩清水幸夫, 超音波による材料内部の応力の評価一音弾性法による残留応力の非破壊評価一, 実験力学, Vol.4, No.4(2004),pp.284-291.

金持昭治，赤星通次郎，水野兼雄，アルミニウムおよび銅多結晶金属における超音波伝ぱ速度の応力依存性と 3 次弾性定数の測定, 材料, Vol.27, No.301(1978), pp.974-979.

金持昭治，水野兼雄，赤星通次郎，超音波伝ぱ速度の応力依存性に関する実験的研究，材料，Vol.26, No.289(1976), pp.982-987.

小堀修身, 岩清水幸夫, 超音波の音速に及ぼす応力と温度の効果, 日本機械学会論文集 A 編, Vol.54, No.498(1988), pp.245-250. 
Newman, J.C. and Raju, I.S., An empirical stress-intensity factor equation for the surface crack, Engineering Fracture Mechanics, Vol.15, No.1-2(1981), pp.185-192.

佐藤次雄，島田昌彦，部分安定化ジルコニアの熱安定性，表面科学，Vol.10, No.1 (1989), pp.1-17

Swain,M.V. and Hannink,R.H.J., R-Curve behavior in zirconia ceramics, in Advances Ceramics, Edited by Claussen,N., Ruhle,M. and Heuer, A.H., The American Ceramic Society, Vol.12(1984), pp. 225-239.

吉川 晃, 池田清彦, 越智 秀, 小堀修身, 部分安定ジルコニアの $R$ 曲線及び疲労き裂進展挙動, 日本機械学会 論文集，Vol.80, No.820(2014), DOI:10.1299/transjsme.2014smm0351.

\section{References}

Claussen, N., Science and technology of zirconia II , The American Ceramic Society in Advances in Ceramics Edited by Claussen, N., Ruhle, M. and Heuer, A.H. (1984), pp.325-351.

Evans, A.G, and Fuller, O.R., Crack propagation in ceramic materials under cyclic loading conditions, Metallurgical Transactions, Vol.5(1974), pp.1-33.

Fett, T. and Munz, D., Determination of v- $\mathrm{K}_{\mathrm{I}}$ curves by a modified evaluation of lifetime measurements in static bending tests , Journal of the American Ceramic Societies, Vol.68, No.8(1985), pp.C-213-C-215.

Hori, S., Strong zirconia -Tough ceramics-(1990), pp.47-49, Uchida Rokakuho(in Japanese).

Hukuoka, H., Acoustoelasticity basis of acoustoelastic theory (1994), pp.2-18, The Japanese Society for Non-Destructive Inspection (in Japanese).

Iwashimizu, Y., Evaluation of stresses in materials with ultrasonic waves -nondestructive evaluation of residual stresses by acoustoelasticity-, Journal of the Japanese Society for Experimental Mechanics, Vol.4, No.4(2004), pp.284-291(in Japanese).

Kanemochi, S., Akaboshi, M. and Mizuno, K., Dependence of ultrasonic velocity to applied stress and third-order elastic constants of polycrystalline aluminum and copper, The Society of material Science, Japan, Vol.27, No.301(1978), pp.974-979(in Japanese).

Kanemochi, S., Mizuno, K. and Akaboshi, M., Experimental studies of the stress dependence of ultrasonic velocities, The Society of material Science, Japan, Vol.26, No.289(1976), pp.982-987(in Japanese).

Kobori, O. and Iwashimizu,Y., Effects of stress and temperature on ultrasonic velocities, Transactions of the Japan Society of Mechanical Engineers, Series A, Vol.54, No.498(1988), pp.245-250(in Japanese).

Newman, J.C. and Raju, I.S., An empirical stress-intensity factor equation for the surface crack, Engineering Fracture Mechanics, Vol.15, No.1-2(1981), pp.185-192.

Sato, T. and Shimada, M., Thermal stability of partially stabilized zirconia, Journal of The Surface Science Society of Japan, Vol.10, No.1(1989), pp.1-17 (in Japanese).

Swain,M.V. and Hannink,R.H.J., R-Curve behavior in zirconia ceramics, in Advances Ceramics, Edited by Claussen,N., Ruhle,M. and Heuer, A.H., The American Ceramic Society, Vol.12(1984), pp. 225-239.

Yoshikawa, A., Ikeda, K., Ochi, H. and Kobori., R-Curve and fatigue crack growth behavior in partially stabilized zirconia, Transactions of the JSME(in Japanese), Vol. 80 , No.820 (2014), DOI:10.1299/transjsme.2014smm0351. 